\title{
Om det private Efterretningsvæesen i 1848.
}

Et lille Bidrag til Laurids Skaus Historie.

Da Meddelelsen om Oprøret spredtes ud over Landet, skabte den en dyb og mægtig Harme, men tillige ogsaa et Offersind og en Forsvarsvilje som aldrig før i Danmarks Historie. Mange meldte sig frivilligt, andre oprettede Frikorps, og rundt i Landet strømmede Gaverne ind i Form af Penge, Heste, Naturalier, Arbejdsydelser af forskellig Art o. m. m. Kampen, der forestod, var Folkets Kamp for "vor Konge" og nationale Are, det var Arvefjenden, man stred imod, og hver brav dansk Mand og Kvinkle følte sig som Deltager, der havde baade Ret og Pligt til at yde sit til Kampens heldige Gennemførelse.

De Steder, hvor Forsvarsviljen viste sig kraftigst, var i Hertugdømmet. Og en af de mest fremtrædende Personligheder her har uden Tvivl Laurids Skau været.

- Under mit Arbejde med Artiklen "Aarøsund i 1848 «') markede jeg den store Interesse, Fjenden nærede for Laurids Skau. Man vilde gerne have ham fanget og udlovedle en Belønning til den, der greb ham. Og da han en Dag havde været i Aarøsund og heldigt var sluppet bort igen, gav en Friskaremand følgende Karakteristik af ham:

Denne mærkværdige Fører af det danske Parti i Nordslesvig har sikkert skadet Tyskerne mere end en hel Hær. Han er Digter, Improvisator, helt igennem en Bonde, men begavet med en glødende Fantasi, ualmindelig dannet og med en umaadelig Magt - i Kraft af sin Personlighed - over sine Medborgere. Hvor han taler, vover ingen at tale imod, hvor han kalder til Vaaben (formodentlig den nordsl. Landst.), der blusser Fanatismen som Ild i Vejret. ${ }^{2}$ )

Selv om denne Karakteristik er overdreven, og det er den, Laurids Skau havde ikke saadan Magt over sine Landsmænd, særlig ikke i Tiden ind til 1848, saa fortjener den dog at ken- 
des, fordi den viser, hvilken Respekt Fjenden havde for ham. Sandsynligvis maatte der ligge en særlig Aktivitet fra Laurids Skaus Side til Grund for denne Interesse og Respekt, men hvilken?

Laurids Skau har intet fortalt or sin Goren og Laden under Krigen i 1848. Hans Historikere ikke heller. Alle standser ved hans Flugt den 25. April og begynder først igen med hans politiske Virksomhed efter Vaabenstilstandens Indtræden.

Men det gør derimod Har’ens Arkiv. I et trykt Bind, der bærer Benævnelsen: Beretningen om Fjenden fra private findes Vidnesbyrd om, hvad der for en Tid var Laurids Skaus Hovedbeskæftigelse. Imellem en broget Blanding af Mhldinger fra forskellige Folk, ikke alle vidnende om Genier, hverken hvad Ortografi eller militær Sagkundskab angaar, wen til Gengacld om den jævne Mand og Kvinde, der i Kærlighed til Fadrelandet, frivilligt satte Livet ind for at skaffe Hæren Meddelelser, der kunde sætte den i Stand til at bekæmpe Fjenden, dér findes en hel Del Breve fra Laurids Skau til Kaptajn Læssøe. Disse Breve danner Grundlaget for efterfølgende suppleret med Oplysninger andetsteds fra.

Den Læser, der tidligere har beskæftiget sig med Laurids Skau, vil let genkende ham: Det frodige Sprog med de mange Ord - de fleste vilde sikkert have sagt det samme paa den halve Plads - hans frejdige Brug af: jeg, "hvad jeg agter at gøre«, "vi blev enige om«, fra en Samtale mellem Landets højeste Militærembedsmand og ham, den fuldkcmmen civile, om et militært Anliggende, hans Fortale for sig selv, hans Overbevisning om sit eget $V^{r} æ r d$, men absolut ikke om sin Begræusning. Forskellige Faktorer, der tilsammen bevirker, at man ikke ubetinget tror paa, at han har eller faar den Betydning, han allerede ved Starten tillægger sig.

Det var vanskeligt for Laurids Skau blot at referere Meddelelser, hans egne Meninger og Formodninger skulde ogsaa med. Saaledes sendte han f. Eks. et Brev til Kaptajn Læssøe, 
scm udelukkende omhandlede "en Idee, som i længere Tid har gjæret i mit Hoved", og som han derfor ikke kunde lade være nıed at fortælle Stabschefen. Planen gaar i sin Naivitet ud paa at faa Fjenden til at "løbe April" ved Aabenraa, eller "fuldstændig at fixere ham» ved Snoghøj. "Saaledes vilde sikkert Napoleon have baaret sig ad«. Ja, Laurids Skau og Napoleon!

Det ses dog ikke, at Laurids Skaus Strategi i særlig Grad har interesseret Stabschefen, det gør den heller ikke os, og derfor vil Laurids Skaus private Meninger ogsaa saa vidt gørligt blive udeladt. (Men de giver unægteligt et lille Indblik $i$, hvad Hærens Officerer maatte tage af patriotiske Borgere). Langt mere interesserer det, at Laurids Skau kastede sig ud i Arbejdet som Leder af et Efterretningsvæsen med Liv og Sjal og, saa vidt det kan skønnes, til Hærledelsens Tilfredshed. Derfor skal der heller ikke gøres miere ud af, hvad ovenfor er fremfort. Laurids Skau er baade hævet til Skyerne og "sat paa Plads«, begge Dele eftertrykkeligt - for eftertrykkeligt, forekommer det mig. Men det vilde være at give et usandt Billede ganske at udelade denne fremtrædende Side af Laurids Skaus Karakter.

- Den 25. April kom Laurids Skau og Pastor Hertel til Kolding - denne Gang i Følge med en Skare fortumlede og skrækslagne Mennesker, der alene var flygtet for Raabet: Preusserne kommer. ${ }^{3}$ )

Rejsen var efter Ludvig Hertels Fremstilling gaaet meget roligt for sig,") antagelig fordi hans Fader var med. Der er jo ogsaa noget beskæmmende $\mathrm{i}$ at flygte, især naar det viser sig, at det var Lygtemænd, man flygtede for.

Oberstleutnant Baggesens Rapport til Krigsministeren fortæller noget andet:

Efter at endnu en Del var kommet og bestyrkede Udtalelserne (at Hæren var tilintetgjort - Aabenraa taget o. s. v.), satte jeg mig med Adjudanten, Premierl. v. Lundbye tilhest og red sydpaa. - Straks uden for Byen modte jeg Oberst $v$. Juel af Livgarden til Fods med Leutnant v. Holten, noget se- 
nere Oberst v. Slagemeyer og Kaptajn v. Benzon sen., dernæst de slesvigske Régerings-Medlemmer: Konferentsraad Kirstein og Justitsraad Lassen, der mer eller mindre bekræfted de tidligere Udsagn. Da jeg dernæst kom til Vonsild Kroe, traf jeg tilhest Laurids Skau og Pastor Hertel, der begge i en noget exalteret Stemning berettede, at alt var tabt, og da jeg mistvivlede herom, da ingen endnu havde kunnet berette personlig at have set nogen Fjende, forsikrede de, at jeg snart vilde møde Artilleriets Heste, der var sendt tilbage, efter at Kanonerne maatte lades i Stikken. En halv Fjerdingvej længere frem mødte jeg derpaa i fuld Karriere en Del tilbagesendte trykkede Heste samt henimod 200 frivilligt stillede Kavalleriheste, der var fra Kolding afsendte sydpaa til Armekorpsets Remontering. De var af Pladskommandanten i Apenrade sendt tilbage. Det var dem, Laurids Skau og Pastor Hertel havde anset for Artilleriets Heste. Medens Adjudanten red over Christiansfeld ti] Haderslev, vendte jeg tilbage for at berolige Indvaanerne i Kolding. $\|^{5}$ )

Oberstleutnantens Skepsis havde dog ikke beroliget de to Herrer. De fortsatte til Kolding og alarmulrede sammen med de øvrige Flygtninge Indbyggerne der.

Fuldmægtig . Saxild i Kolding er ikke særlig venlig mod Laurids Skau i sin Indberetning til Amtshuset i Vejle. Han skriver, at "......denne Skræk traf ikke allene Soldaterne, men ogsaa Folk, om hvem man ikke skulde have tænkt sligt, saaledes var Laurids Skau som en af de første, som kom hertil Kolding for at udbrede de fabelagtigste Rygter, istedetfor at indfinde sig for at sæette Mod $\mathbf{i}$ den Landstorm, som han roser sig af at have været med til at organisere i det nordlige Slesvig. Stemningen var her i Gaar meget nedtrykt, og ikke faa Familier, dog mest den quindelige Del af samme, flygtede til Fyn, idag er der kommet mere Rolighed i Gemytterne, og jeg antager, at de fleste Flygtninge er vendt tilbage........")

Fra Kolding rejste Laurids Skau til København, og igen- 
nem Samtaler med Krigsministeren i Begyndelsen af Maj blev hans fremtidige Arbejde bestemt.

Da Krigen i 1848 udbrød, var det danske Hærvæsen i høj Grad ufuldstændigt, og meget maatte bygges op helt fra Grunden. Efterretningsvæsenet dannede ingen Undtagelse herfra, det tilfredsstillede end ikke de tarveligste Fordringer. ${ }^{7}$ ) Ganske vist havde Krigsministeren den 28. Marts anmodet Justitsministeren om at organisere et spionagevæsen og træffe Foranstaltninger mod fjendtlige Spioner, dog uden at dette førte til noget virkeligt. Ministeren fik opgivet Navnene paa en Del Mænd, som man fandt egnede til dette Hverv; men intet tyder paa, at der ad den Vej udrettedes noget. ${ }^{8}$ )

Spørgsmaal om Spioner eller Spejdere, som man yndede at kalde dem, hvis det var ens egne - det var kun Fjendens Spejdere, man kaldte Spioner, en særlig nedsættende Betydning fik Ordet, hvis det gjaldt en Landsmand, der gik Fjendens Erinde - ordnede man, efterhaanden som der var Brug for dem, eller nøjedes med de Oplysninger, Folk selv fandt paa at bringe. Laurids Skau har ogsaa bragt Meldinger til Hæren i den Tid. Den 5. April foreligger saaledes en Melding fra ham til Kommandanten i Haderslev om Friskarerne. ${ }^{9}$ ) Det var hel. ler ikke vanskeligt at faa Folk, Krigen var populær; men Følgen af Systemet var dog, at Hæren under sin forste Fremrykning i Sønderjylland faktisk var uden noget paalideligt Kendskab til Fjenden og derfor afskaaret fra enhver nogenlunde sikker Beregning." der foreligger.

$\mathrm{Nu}$ i Maj Maaned var Stillingen en anden. Den danske Hær var trukket tilbage til Als og Fyn, og Fjenden havde besat Sønderjylland og Vejle Amt. Nogen direkte Fare truede altsaa ikke de danske Styrker; men det var selvsagt alligevel af aller største Vigtighed, at Hærledelsen formaaede at holde 
sig underrettet om Begivenheder i det af Fjenden besatte Omraade.

Det ordnede Efterretningsvæsen manglede.

Da var det, Laurids Skau kom til Københavu. Som den Mand, han var, og med det rige Lokalkendskab, han sad inde med, kunde han under saadanne Forhold umuligt holde sig uden for Spillet; og han er sikkert kommet, som var han kaldet.

Et Brev til Kaptajn Læssøe fortæller:

Odense Præstegaard, d. 12. Maj 1848.

Herr Capt. v. Lassue!

For ikke at falde Dem besvarlig mere ond høist nødvendig, tillader jeg mig at medilele Dem skriftlig, hvad der har bevæget mig til at rejse her til Byen.

Krigsministeren beklagede, at, medens Fjenden havde Spioner overalt, syntes vi enten ganske eller tildeels at mangle disse, og foreslog mig derfor at organisere Spioneriet planmassig, deels fordi jeg havde personligt Bekjendtskab, deels fordi jeg kendte Kysten og Egnen. - I flere langere Samtaler desangaaende, i hvilke jeg sogte at oplyse, hvorledes jeg vilde begynde, gennemgik han med mig Alt, hvad der havde væsentligt Værd for Høistkommander'ende at vide, og lærte mig sluttelig et hemmeligt Skriftsprog, som jeg med storste Lethed kunde lære de enkelte Fortrolige, der kunde stoles paa. ......

Fremdeles mente Krigsministeren, at, medens In $\mathbf{g}$ en lurde vide $\mathrm{h}$ vem jeg brugte til at sende til de forskellige af I'jenden besatte Egne, var det ikke nødvendigt at holde mig selv skjult, for at den eller de, som vilde og kunde meddele Noget, kunde finde mig. Endelig billigede han fuldkommen, at jeg erklærede ikke at ville have med Andre end med Dem, Herr Captajn! at bestille, og at altsaa Alt, hvad jeg kunde faae at vide, skulde meddeles Dem ganske privat. - Hvad der nærmere kunde være at aftale i dette Anliggende, tilføiede Krigsministeren, burde være med Dem, og navnlig ansaa han det for gavnligt, at jeg herfææa fik et Leidebrev, der maaske skulde paa- 
tegnes af Commandør Paludan, for at vore egne Krydsere ikke skulde optage mig, naar jeg om Natten seilede ud i en Baad, for at indhente Efterretninger o. s. v.

Vi bleve enige om, at Assens kunde være et hensigtsmæssigt Sted at boe, eller have til Hovedkvarter, fordi Forbindelsen derfra kunde vedligeholdes til alle Sider, navnlig ogsaa søværts ......... For at realisere et sligt Foretagende, der ingenlunde er let, maatte jeg selvfølgelig tage Folk i Tjeneste, og de fornødne Penge, formeente Krigsministeren, burde anvises fra Hovedkvarteret eller af Dem, som i denne Henseende havde fuld Bemyndigelse, da det laae i Sagens Natur, at jeg ikke selv kunde eller skulde betale sligt. Endelig ytrede han, at De ventelig kunde rekvirere Qvarteer til mig i Assens eller meddele nig Fuldmagt til at gøre det selv.........

Jeg tilføjer, at jeg foreløbig har sikkret mig en fuldkommen paalidelig ung Mand, som er født og opdragen i Rendshorg, og som vil lade sig landsætte i Egnen ved Apenrade og gaae lige til Rendsborg eller længere, hvis jeg vil have det; ligesom jeg allerede har Øie paa flere Andre, der kunde bruges $i$ andre Egne.

I foranførte Linier har jeg nedskreven det væsentligste af det, som jeg ellers skulde have sagt Herr Captainen mundtlig. I Morgen skal jeg tillade mig at komme til Dem for at udbede mig Deres Mening tilkjendegivet. Synes Deres Velbaarenhed om min Plan, saa skal den inden i Morgen Aften være paabegyndt; synes De ikke om den, - nu ja, saa gaaer jeg til Kjbhvn. igjen, og fører den Overbevisning med mig, at jeg har gjort min Pligt, idet jeg har tilbudt mig at forsøge det, som jeg maaskee kunde gavne noget med, - som fast er det eneste, jeg for Øieblikket kan gjøre, - og - tillad at jeg siger det selv — som maaske kun faa vilde indlade sig paa.

Skulde Deres Velbaarenhed kunde bruge mig til noget Andet, eller formene at have noget gavnligere at anvende mine Kræfter til, saa følger det af sig selv, at jeg er til Disposition. Da De imidlertid kun har kjendt mig saa kort Tid, være 
det mig tilladt, at anføre, at jeg har reist overmaade meget, levet med alle Klasser i Samfundet, fra de høieste til de laveste, og erhvervet mig en temmelig Øvelse $i$ at tale med forskjellige Mennesker. Desuden er jeg af en seig og kraftig Natur, der er hærdet ved Strabadser, og hvis altsaa en eller anden voldsom og anstrengende Tour skulde gjøres, enten med Depeche eller noget lignende, hvor der ikke kunde undværes nogen af Deres Omgivelser, - da er jeg altid til Deres Tjeneste. Det latterlige i, at jeg skriver min egen Anbefaling, beder jeg undskyldt, formedelst Omstændighederne.

Med udmærket Høiagtelse, har jeg den Ere at kalde mig

Deres Velbaarenheds

ærbødige

Laurids Skau. ${ }^{11}$ )

Dagen efter talte de to Mænd sammen, og Resultatet blev, at Kaptain Læssøe gik ind paa Planen og udstedte følgende Pas til Laurids Skau:

Foreviseren heraf, Hr. Laurids Skau skal passere uhindret af alle til det nørrejydske Korps henhørende Troppeafdelinger, saavidt saadant kan skee uden Skade for den kongelige Tjeneste, og anmodes alle andre Autoriteter og navnlig den kongelige Marine om at give Hr. Skau den Assistance, som han maatte behøve, og som Omstændighederne tillade.

Hovedkvarteret i Odense

d. 13de Maj 1848.

\section{Efter Befaling}

W. H. F. A. Læssøe,

Captain og Stabschef

ved det nørrejydske Korps. ${ }^{12}$ )

$\mathrm{Nu}$ var Laúrids Skau Spejder. Han afrejste straks til Assens og virkede under Besættelsen af Jylland herfra, senere fra Haderslev og forskellige andre Steder. Med stor Energi udviklede han sammen med Mænd som Hans Krüger, de to 
Studenter H. C. Refslund og Adolf Kroyer ${ }^{1}$ ), Peter Lund fra Skærbæk, Chr. Reinholdt, A. S. Sørensen og andre et Net af Spejdere, der spændte over hele Nordslesvig.

I det skjulte arbejdede disse gode Patrioter. De kampede for deres Fædreland saavel som Soldaten, og deres Færd var ikke mindre farefuld; men efter Krigen gled de igen ud i Glemselen, for, som der blev sagt: "Paa den Valplads vindes der jo aldrig Laurbær.« Saadan er Spionens Lod, mens Soldaten faar Virakken. Derfor er det ogsaa kun lykkedes at finde enkeltes Navne, de skal nævnes og æres sammen med de mange navnløse Kammeraters: Bissekræmmerens, Haanılvarkssvendens, Fiskerens og mange andres.

De var i høj Grad Amatører, hvad selvfølgelig prægede Arbejdet, saa deres Meddelelser ofte var tilfældige og mangelfulde og ogsaa værdiløse. En Sammenligning af deres Meldinger med de forskellige Afdelingschefers Rapporter og med den officielle Beretning om Krigen vil ogsaa vise, at nogle var vildledende, i Strid med de faktiske Forhold og sikkert har voldt de Mennesker mange Bekymringer, som skulde benytte dem.

Et morsomt Eksempel af den Slags - det er fra Sommeren - skal nævnes:

- - - Den Mand, der bragte mig Budiskabet (om en preussisk Fremrykning), er Ludvig, der havde hørt det af Rebslageren i Strandelhjørn, hvem han erklærede for en paalidelig Mand, og som var kommen i Gaar Middags fra Apenrade, hvor det var bleven ham fortalt, at Prøjserne fra Bau om Natten vare ankommen til en Mølle, hvis Navn Ludvig havde glemt,

1) Efter Samraad med Regeringen rejste Professor Flor til Nordslesvig for at forsøge at rejse en Folkehter mod Slesvigholstenerne. Med ham fulgte en Del slesvigske Studenter, som onskede at drage hjem for at hjælpe paa Stemningen. (Th. Roust: Chr. Flor).

Adskillige af dem gik i Efterretningsvasnets Tjeneste, bl. a. H. C. Refslund og Adolf Krøyer, der gjorde den danske Hær store Tjenester under Krigen.

Senere blev H. C. Refslund Koginspektør i Tønder (1852) til 1901. Han døde 1902. - Var gift med Maren Knudsen, en Søster til H. A. Knudsen paa Trøjborg. 
ca. 1/2 Mil Syd for Apenrade. Han troede det saa meget mere, som 13 Bagerkjellinger droge derud med Hvedebrød. Idag maae vi vel have et Menneske derned for at see det rigtig efter; men Gud maa vide, hvem vi kumne faae? Der blive vel Raad derfor, imidlertid er det vel bedst at oppebie Ciarolines IIjemkomst? ${ }^{13}$ )

Man maa indrømme, at det ikke har varet let at lagge en Plan efter den Melding, og det kunde være meget rigtigt at faa et Menneske derud for at faa Sagerne set efter. Eksemplet anføres for at vise en Type, der nodvendigvis maatte komme under saadanne Forhold.

Vejene var heller ikke altid de slagne. En københavnsk Smedesvend havde forsøgt at gaa gennem Fjendens Linier, men blev fængslet i Aabenraa. Han kom til at sidde i Arresten sammen med "Mathies Skrædders Søn, Christian«. Til ham fortalte han, hvad han vidste, og da Christian blev løsladt, gik han til General Hedemanns Stab og folrtalte det. ${ }^{14}$ )

Generalstabens Værk om Krigen $1848^{15}$ ) fortæller, at Beboerne var i højeste Grad interesserede $i$ at holde Overkommandoen underrettet om Fjenden, og at Ledelsen ved disse Efterretuinger valr i stand til temmelig nøje at følge enhver Bevagelse af denne. For Iveren var der. Krigsforelsen var jo heller ikke den Gang saa udviklet og fuld af uhyggelige Overraskelser som nu, og som Følge heraf betød Efterretningsvasnet heller ikke det, det betyder nu, hvor speciel Uddannelse kraves. Den eneste Egenskab, en Spion nodvendigvis mantte være i Besiddelse af, var Frygtløshed i Forbindelse med Snuhed; men denne Egenskab forekom ogsaa i rigt Maal og opvejede dermed det. inanglende Kendskab til Faget.

I d'enne Forbindelse skal nævnes, at kunde man ikke forlade Hjemmet for at tjene Haren som Spejder, saa var man dog ikke derfor afskaaret fra at yde sin Tjeneste. Man kunde altid staa i Forbindelse med Spejderne som Bagmænd og skaffe dem Oplysninger, de selv var ude af Stand til at opsnuse.

Og det gjorde mange, skønt Efterretningstjenesten absolut ikke var nogen ufarlig Beskæftigelse, hvad ogsaa efterfølgende 
Breve vil vise. En Tur til Rendsborg kunde man let opnaa, Fjenden havde jo ogsaa sine Spejdere ude, og med Tiden opsnusede de som Regel, hvem det var, der skaffede Danskerne Nyt. "Det var en grusom Scene«, skriver Hans Krüger om en Tilfangetagelse, han skjult var Vidne til.

Om Faren ved Spejdernes Færd vidner følgende Brudstykke:

..... I forgaars fik jeg fra Student K. i B. en Meddelelse, hvori han fuldkommen indser, at vi maa holde op med de daglige Meldinger ..... dette kom os særdeles belejligt. thi Faren ved den daglige Afsendelse af Meldinger er med hver Dag bleven mer og mer truende. Alle ved af det at sige, og ei Alle ere paapasselige, end sige forsigtige; til Tonder vil Ingen, hverken for gode Ord eller Betaling, gaae for at udspejde Tilstanden, og de idelige Patruiller (paa 1 eller 2 Mand), der gennemstrejfe Egnen, gjør ved deres Aarvaagenhed Sagen end mere vanskelig......

\section{Erbødigst \\ Hans Clemmensens}

Contubernal. ${ }^{16}$ )

Men nu sidder altsaa Laurids Skau i Assens og sencler sine Medhjælpere ud, modtager Rapporter og sender disse videre til Kaptain Læssøe i Odense.

For at forstaa de Forhold, de arbejder under, og Betydningen af, hvad de udrettede, skal den militære Situation i korte Træk opridses.

Den danske Hær var efter Slaget ved Slesvig den 23. April trukket bort fra Hertugdømmets Fastland. En Del stod paa Als, overfor den de tyske Forbundstropper, en anden Del var samlet paa Fyn.

Den forenede preussisk-slesvigholstenske Hær under General Wrangel personlig havde gennemført Fremrykningen op gennem Hertugdømmet og havde nu besat det sydøstlige Hjørne af Jylland (Vejle Amt) som Repressalie for den danske Flaa- 
des Blokade af de nordtyske Havne, Resten af Halvøen laa aaben. Dette sidste Skridt havde mødt nogen Modstand fra Slesvigholstenerne; men det brød General Wrangel sig ikke om. $\mathrm{Nu}$ haabede han, at en gennemfort haard Besættelse med store Tvangsudskrivninger, Indkvarteringer o. l. skulde gøre den danske Regering tjenlig til at slutte Fred paa de opstillede Vilkaar.

Efter en ren overfladisk Betragtning skulde General Wrangel kun have Grund til at være tilfreds og bare vente og se Tiden an.

Det var imidlertid ingenlunde Tilfældet, tværtimod var Generalen højst utilfreds. For det forste af rent personlige Grunde.

Rundt i Europa var der nu i Aarets første Maaneder opstaaet Revolutioner, som alle drejede sig om Sporgsmaalene: Folkefrihed og Folkeuafhængighed, og Tyskland havde faaet sin Part. Hæren havde bekæmpet dem - ikke alle Steder med lige stort Held, og forskellige Troner havde vaklet, dog var der nu nogenlunde Ro.

En af de ivrigste paa "Lovlighedens Side" havde General Wrangel varet. Hans politiske Trosbekendelse var det uindskrænkede Kongedømme, i hans Øjne var derfor enhver Frihedsmand en formastelig Oprører, der vovede at satte sig op mod den af Gud indsatte Øvrighed.

Men nu vilde Skæbnen, at den samme General Wrangel kort efter skulde blive sendt op i de danske Hertugdømmer for at give Slesvigholstenerne Preussens Støtte under et Oprør mod den danske Konge, hvor det gjaldt de samme Sporgsmaal, endda paa Trods af Forbundsbestemmelserne, der sagde, at han $\mathrm{i}$ et saadant Tilfælde tværtimod skulde støtte den danske Konge. ${ }^{17}$ )

Det var under den aldrende Herres Værdighed, og han og hans preussiske Garde, der under Revolutionen lige var jaget ud af Berlin, befandt sig rigtig daarligt i Selskahet med Slesvigholstenerne og de tyske Friskarer. Langt hellere end at 
hjæpe de slesvigholstenske Oprorere vilde de - det sagde han selv - hjem og slaa løs paa deres egne Oprørere $\left.{ }^{14}\right)$, og utallige var de Sammenstod af forskellig Art, baade store og smaa, der skete mellem de to Parter. ${ }^{19}$ )

Iren pinte end dette, saa var der dog andre Ting, der voldte Generalen langt alvorligere Uro.

Besættelsen havde varet er uklog Handling, der havde givet Genlyd i Udlandet og allerede faaet visse Følger.

Den 29. April havde den preussiske Gesandt i Stockholm meldt sin Regering, at Stemningen i Sverige var i stærk Stigen, og at en tysk Har's Indrykning i Jylland sikkert vilde fore til kraftige Demonstrationer.

Den 4. Maj skrev Kong Oskar til Frederik VII., at han i Tilfælde af et Angreb paa Jylland vilde være villig til at sende et Armekorps til Fyn.

Den 9. Maj gav den svenske Regering den tyske Meddelelse $\mathrm{cm}$, at 15000 Mand var samlet ved Gøteborg og i Skaane.

I ret fjerne truede Rusland. Den slesvigholstenske Bevægelse var den russiske Kejser inderlig imod, han tilstillede den preussiske Konge en Note, hvori han krævede Romning af Norrejylland og truede med i modsat Falld at sende en Ekspedition ind i Østpreussen.

I England var Folkestemningen paa Danmarks Side, men Regeringen nærmest paa Tysklands. Man vilde dog nødig, at Tyskland fik storre Adgang til Havet, og endnu nødigere Konflikt med Rusland. Derfor søgte den engelske Regering at mægle, men ikke uden at lægge et vist Pres paa Preussen, der samtidig var under Tryk af de nordtyske Handelsstæder, som led haardt under Blokaden. ${ }^{20}$ )

Preussen følte sig isoleret, medens Danmark følte sig stærkere og dristigere, og Friherre v. Arnim sendte den 9. IIaj et Brev til General Wrangel, hvori han betonede, at det var onskeligt snart at komme til Ende med Fjendtlighederne.

Besættelsen havde hverken virket paa den danske Regel'ing eller Befolkningen, som General Wrangel havde onsket; og 
trods dens Haardhed havde den i Stedet for Frygt kun skabt Modstand og Had, som sandelig ikke undgik Fjendens Øjne. I Begyndelsen af Maaneden foretog nogie Soldater, for at nævne et Eksempel, under Ledelse af en frivillig et dristigt Togt fra Fyn til Sdr. Stenderup, hvorfra de en tidlig Morgenstund bortfarte de bekendte Slesvigholstenere, Kammerjunker v. Krogh og Skovrider Schrader, lige for Næsen af den tyske Besætning paa Stedet. ${ }^{21}$ ) Saa stor var U'sikkerheden, at const. Amtsforvalter Eden i Haderslev efter dette ikke længere turde beholde den ham betroede slesvigholstenske Krigskasse af Frygt for, at noget lignende skulde ske med ham, eventuelt med Støtte fra Befolkningen, men anmodede om at faa den sendt til Kolding, hvor den preussiske Krigskasse fandtes. ${ }^{22}$ ) Stort bedre var det dog ikke her, for Huset, hvor Krigskassen opbevaredes, blev afbrændt, efter at der tidligere havde været Ild i det. Krigskassen blev reddet. ${ }^{23}$ ) Branrlen var sandsyriligvis paasat og et Ldslag af Befolkningens Had.

Dette og mere af samme Slags, i Forbindelse med den Optræeden, der overailt blev vist Fjenden, var nok til at gøre det klart for General Wrangel, at med Hensyn til den Side af Sagen havde han ogsaa forregnet sig.

- Greneral Wrangel skal engang have sagt: "Jeg skriver nied Sværdet og ikke med Pennen; jeg gider ikke se Papirer. $\ll^{24}$ ) Han var Typen fra Napoleonskrigenes Tid, Diplomati laa ikke for ham. Derfor saa han heller ikke saa ineget de Skyer, der viste sig paa den diplomatiske Himmel. Den Fare, der $\mathrm{i}$ hans Sind antog den storste Dimension, var, at Sverige vilde sende et Armékorps til Fyn. Det foruroligede ham, og han saa for sig den Eventualitet, at han af den Grund kunile blive nødsaget til at rømme Landsdelen, og njeg vil anse det for en Skandale, om det skal blive nodvendigt at romme den sejrrigt vundne Jord, som er Basis for en fast og ærefuld Fred. $\left.\alpha^{25}\right)$ Han anmodede derfor om Forstrorkning paa 10,000 Mand til at imødegaa et eventuelt svensk-dansk Angreb. 
Den 9. Maj inspicerede General Wrangel Tropperne i Sundeved. Rejsen havde ikke gjort hans Humør bedre, og hjemkommen traf han forskellige Foranstaltninger til Forsvar mod en Fjende, der tænktes at angribe ham og tvinge ham ud af Jylland. ${ }^{26}$ ) Navnlig samlede han sin Opmærksomhed om Egnen omkring Aabenraa, i hvilken By han lod indrette Magasiner med Forplejning for Hæren i 5 Dage. Her var det Meningen at optage Kampen mod den fremtrængende Fjende (Planen blev igen opgivet). Disse Magasiner er sandsynligvis for en Del blevet fyldt af Vejle Amts Indbyggere, som netop i denne Tid blev paalagt større Byrder og blev tvunget til at køre Mængder af Furage i lange Vogntog Syd paa. ${ }^{27}$ )

For at sikre sig Plads under en eventuel Retræte, gav General Wrangel Befaling til Anlæggelsen af Kolonneveje fra Kolding og Syd paa.

Laurids Skau fortæller herom:

... I Aftes meget sildig kom endelig en Mand tilbage, som jeg to Dage med Længsel har ventet. Min Bonde kunde ikke komme til Landet; men en forvoven Fisker fra Vonsbæk lod sig moid stærk Betaling bevæge til at sejle ham over, men som nu ikke kan komme tilbage igen. Han har gennemvandret Linien fra Apenrade til Kolding og afgiver følgende Beretning: Der er bygget to Broer over Koldingaa imellem Byen og Skodborghuus ${ }^{28}$ ) og Veje anlagte fra disse i Retning af Vonsyld.

En ny Vej er anlagt fra Kolding til Apenrade og videre. Den er i Begyndelsen 20 Alen bred, men bliver efterhaanden smallere, undtagen ved Kjøbstaderne, hvor den altid er bred. Den løber fra Kolding jæunsides $1 / 4$ Miil østlig med Kongevejen; derpaa falder den igen ind paa Kongevejen, som her og der er udvidet, indtil Bjerning Kirke, hvor den løber ind igennem Skoven ved den saakaldte Kirkevei, igennem Byen Raugstrup, østlig forbi Moltrup; derpaa i omtrent lige Retning østen om Hammelef til Tørningmølle og videre i Syd, indtil den kommer til en Kroe, kaldet Faarhus (?) ved Flensborg Landevei, 
hvor den igen løber til venstre ned imod Bodum Bye ved Apenrade; derfra gaaer den vestlig forbi Apenrade i Dalen østlig nedenunder det saakaldte Skeibjerg eller Skinkelsbjerg en lille F'jerdingvei vestlig for Byen. $\left.-{ }^{28}\right)$

I et andet Brev skriver han om dette Stykke af Vejen:

- - - I mange Dage har Fjenden arbejdet paa en ny vej, som de med stor Anstrengelse anlægger udenom Apenrade, og som indrettes saaledes, at den vanskeligt kan beskydes fra Fjorden. Bønderne tvinges til at hjælpe til med Folk, Heste og vogne, og disse ere naturligviis misfornøiede dermed. De raillere over Hensigten med denne Vei og paastaae, at den skal bruges, naar Fjenden nødes til en hurtig Flugt. - - -

En Mand ved Navn Hein (Spejder), som har været i Christiansfeld hos sin Moder, fortæller i et Brev til General Hedemann, dat. 25. Maj, om Vejen direkte syd for Kolding:")

- - - Vejene førte over Kongeaaen ved Seest, ca. 1000 Skridt Syd for Krathuset var der gjort Gennemhugning fra I.andeveien, der krydsede Kolonnevejen. - - -

Som man vil se, har disse Amatører formaaet at foretage en ret indgaaende Undersøgelse af det foreliggende Forhold og skaffet sikkert meget velkomne Meddelelser til den danske Overkommando.

- Omkring Midten af Maaneden modtog General Wrangel Efterretninger, gaaende ud paa, at Als var kun svagt besat, medens Hovedstyrken var koncentreret paa Fyn..$^{30}$ ) Det kunde tyde paa, at der fra dansk Side forberedtes en Overgang til Jylland, kun vidste man ikke hvor. ${ }^{31}$ )

For at imødegaa et saadant Angreb fik General Halkett Ordre til fra Sundeved at skyde en Del af sine Tropper frem

") Den 28. Marts 1848 skrev Carl Ploug til Laurids Skau, (Hother Ploug: Carl Ploug I): - - - I mangle Vaaben, hører jeg fra flere Sider f. Eks. fra en af de afrejste Studenter, der er i Vonsbæk. Men I skulle nok faa o. s. v.

Fra samme Dag foreligger en Melding til Hovedkvarteret (I. S. 17) fra en Mand ved Navn Hein, der organiserer Folkevæbningen derude.

Disse to er sandsynligvis samme Person og identiske med den her nævnte, altsaa ogsaa en af Flors slesvigske Studenter. 
til Egnen: Aabenraa-Haderslev for at tjene som Reserve for de preussisk-slesvigholstenske Tropper, hvis de skulde blive angrebet og tvunget tilbage. General Halkett opslog sit Hovedkvarter i Aabenraa. ${ }^{32}$ )

Vi skal se, at heller ikke disse Troppeforskydninger undgik Laurids Skaus og hans Medhjælperes Opmærksomhed, og de bringer straks Kaptain Lassee Bud derom.

Sandsynligvis paa et Spørgsmaal fra Kaptajn Lossøe om Troppernes Placering svarer Laurids Skau den 16. Maj:

- - - Om det i Sundeved værende Troppekorps kunde jeg intet Paalideligt erfare; men saasnart Bønderne faae nogen Underretning baade on dette og andet videværdigt, vil de give Rapport til mig. - - -

Senere skriver han:

- I Apenrade er nu ankommen omtrent 3000 Mand Hannoveranere og Brunsvigere, deels fra Sundeved, deels fra nogle vestligere Landsbyer, hvor de var indkvarterede. I Haderslev var der omtrent 1600 Mand, som i Søndags gik sydpaa til Apenrade. Han (Spejderen) kan imidlertid ikke med Vished sige, om disse 1600 ikke skulle være medberegnede i den i Apenrade værende Besætning, ca. 3000 Mand, som er forsynede med 12 smukke Metalkanoner, sexpundige, der ligger $i$ en Kobbel ved den vestlige Indkjørsel til Byen. - Til Haderslev er igen ankommen 300 lauenborgske Jægere s yd fra, og efterhaanden 121400 Preussere og Lyneborgere, af de sidste 800 Mand, hvilke maaske ere kommen nordfra. De ere forsynede med 8 firepunds Kanoner. - Nogle enkelte svare Kanoner skulle ogsaa være der, men som vare bestemte til Aarøsund, hvor Fjenden har stærkt i Sinde at erobre Kutteren og Aarøe. En Masse Tommer til Flydebroer eller Sligt ere til den Ende transporteret dertil. Vi have imidlertid derom givet Kutterens Fører, Lieutnant Schmidt, udførlig Underretning. ${ }^{33}$ ) (En Spejder, S. A. Sørensen, meldte den 18. Maj, "at i Haderslev beskæxtiger de sig med at bygge Flydebroer, men hvor de skal bruges, ved man ikke.) I Gram ligge 180 Itzehoer-Dragoner, der ere sendte saa langt ud 
fra den egentlige Linje, fordi de skail have erklæret ikke at ville slaas med de Danske, som de kalde Landsmænd.

I Christiansfeld var der i Fredags 700 Mand med 12 a 16 Kanoner, det er Tropper af alle Vaabenarter, som ligge paa de ovenbenævnte Steder. - Fra Christiansfeld til Kolding er stærk Indkvartering hele Veien, næsten lutter Preussere. - I Kolding med omliggerıde Byer indtil Christiansfeld incl., ligger ialt omtrent 7000 Mand. I Byen staae 16 daarlige Feldtkanoner. - -

Laurids Skau skriver, at Manden, der har bragt Meldingen, er indfødt Slesviger, som nu bor i Assens. Han har tidligere været Artillerist, saa hans Dom betyder lidt mere end mange andres. - Alt ialt ogsaa en Melding, der absolut bærer Troværdighedens Præg.

General Wrangel følte sig truet paa flere Punkter. For det første fra Egnen omkring Fredericia. Den tidligere nævnte Hein fortæller i sit Brev til General Hedemann efter at have talt med preussiske Officerer, "at de troede ikke, at det var Wrangels Plan at lade det komme til Slag i Jylland, kun troede de, at Fredericia vilde blive forsvaret en Tid, dog ei længere end at de Tropper, der ere $\mathrm{i}$ og omkring Veile samt Vest mod Foldingbro kunde koncentrere sig ved Vonsyld, og hvor Generalen efter at have trukket Avant- og Arrieregarden hertil, vilde forsvare Stillingen mellem Kolding og Vonsyld.“

Denne Melding bekræftes af Laurids Skaus Artillerist, der fortaller, at "i Vonsyld ere Bønderne blevne opfordrede til at flytte alt deres Gods bort, som de da har sendt til Skanderup, og Byen bruges nu ganske af Fjenden, som siger, at den ventelig vil blive afbrændt $i$ den forventede Bataille. - _ _ * )

Dernæst frygtede Generalen en Overgang paa Strækningen Nord og Syd for Haderslev Fjord. "Kysten fra Stenderup til Heils skal være stærkt besat, da man stadig frygter en Landgang«, (S. A. Sørensen), Kyststrækningen Syd paa blev bevog-

*) Maaske har General Wrangel, efter at Planen om Forsvaret ved Aabenraa var opgivet, valgt at modtage et Angreb her. 
tet af Friskarerne, i Aarøsund Aldosser, Syd for Aarøsund af Rantzaus Frikorps med Stabskvarter i Hoptrup.

Laurids Skau fortæiller om Fjendens Forsvarsforanstaltninger i den Anledning:

I dette Øieblik kom jeg hjem fra mit Krydstog til Halvøen og iler med at afgive Beretning. - -

Jeg seilede herfra iforgaars Aftes, landede ved det saakaldte "Halkhoved ", hvor en gammel Ven meddelte mig, at der laa en Mængde Friskarefolk [i Egnen] - - -

Fra Halkhoved seilede vi - 4 Mand - til Barsøe, hvor jeg atter traf gamle Bekjendte. Jeg formaaede et Par solide Bønder til strax at reise til Haderslev, under Foregivende af at ville kjøbe Sviin, og imedens disse vare borte, landsatte jeg en i Sønderborg født og opdragen Mand, der er Sømand, Tømmermand, Dreier, kort sagt alt muligt, og om hvis Paalidelighed jeg troer mig overbeviist, da jeg lige fra Krigens Begyndelse har kjendt og brugt ham. - Han skal nu gaae til Apenrade (han hed Carl Röhlk) og Flensborg og bringe Oplysninger om alt, samt udsøge sig Tilknytningspunkter, hvor han altid kan faae Efterretninger herefter. - Naar han kommer tilbage og røber Duelighed, har jeg i Sinde at sende ham til Slesvig og Rendsborg. - _ - - De to Bønder fra'Barsøe kom i Aften tilbage og meddelte, at $-\ldots+\ldots$ paa den saakaldte Strandvei imellem Vilstrup og Hoptrup Sognes søndre Deel, i Nærheden af den Sluse, hvorigennem Vandet falder ud i Beltet af Indsøen Slief, ind imod Hoptrup, traf min Udsending 6 Minører, klædte i blaae Vaabenkjortler og hvide Beenklæder, som gravede dybe Huller paa og ved Veien, deels lige need $\mathbf{i}$ Jorden, deels paa skraas ind under Jorden. De bleve arrige over, at Bønderne med skarp Opmærksomhed betragtede deres Arbejder og blev skarpt forhørte af en Officer, som de antoge havdle Opsyn med Arbeidet (sandsynligvis en Ingeniør); da Bonderne imidlertid erklærede, at de var fra Synderballig, havde sl.-holstensk Cokarde paa Hatten og brækkede med stor Iver og Anstrengelse paa det tydske Sprog, saa slap de med 
Irettesættelse for deres Nysgerrighed og Løfte om Taushed. Dette sidste vidste de dog ikke, om de havde forstaaet rigtigt, da de ikke vidste, hvad Taushed hedte paa Tydsk. - Bønderne meente, at Fjenden frygtede for en Landgang af vore Tropper $i$ Hoptrup Bugt, og at de derfor anlagde Miner eller desligeste, eller i al Fald gjorde Veien vanskelig at passere $--\ldots$

Endelig frygtede General Wrangel et Frembrud fra Als.

Efter at Troppernes forandrede Stillinger var tilendebragt, udsendte General Wrangel den 22. Maj forandrede Bestemmelser for de Operationer, Hæren kunde faa at udføre $i$ den nærmeste Fremtid. ${ }^{34}$ )

Overgeneralens Uro forplantede sig nedad baade til Befalingsmæend og Menige. Der var Misstemning blandt Slesvigholstenerne. Generalstabens Værk fortæller: - - - I alle Efterretninger, der modtages fra de Egne, der er besat af Insurgenttropper, fandtes saa godt som gennemgaaende den samme Meddelelse, nemlig om disse Troppers Utilfredshed over ved falske Forestillinger at være blevne dragne ind $i$ en Kamp, hvis Formaal ingenlunde stemmede med deres Anskuelser og Ønsker. ${ }^{35}$ )

I en Meddelelse til Hovedkvarteret fra Vejle, dat. 8. Maj, fortælles:

— - - Forleden Aften traf jeg en Del. (Slesvigh.) Jeg gav mig i snak med dem, og da jeg hørte dem beklage sig over at være forførte og tvungne, sagde jeg til dem: Kongen kommer her om nogle Dage, hvad ville I da sige til ham, naar han taler til sine Soldater? Svaret var: "Wenn der König nur käme! - aah, wir liefen ihm mit offenen Armen entgegen! (3) $^{38}$

Hertugen af Augustenborg maatte omgive sig med preussisk Vagt og optraadte i forskellig Forklædning, naar han kørte ud. - Derom vidner flere Meddelere. Prinsen af Nør lavede sig ligeledes en særlig Livvagt af holstenske Forstmænd fra et af Frikorpsene. ${ }^{37}$ ) 
Stemningen blandt de preussiske Officerer var ikke meget bedre. I en Avis blev der klaget over Preussernes Mangel paa Forstaaelse af Slesvigholstenernes Sag. En preussisk Officer svarede: Ja! da hat der Schreiber ganz Recht. Was geht uns die Sache an! Wir fechten, weil es uns befohlen ist! ${ }^{38}$ )

Spurgte man en preussisk Officer nærmere ud om, hvorfor han befandt sig saa daarligt her og ikke kunde lide Slesvigholstenerne, vilde Svaret blive: fordi han var Royalist, fordi han, da han kom ind i Landet, troede, at han som tysk Soldat skulde hjælpe til at sprænge tyske Brødres Slavelænker, men saa fandt han rige Bønder, der levede som Herremænd, og han saa sig pludselig i Forbund med Revolutionen, som han foragtede, da han tilstrækkeligt havde lært den at kende $\mathrm{i}$ Berlin. ${ }^{39}$ )

Om Stemningen skriver Laurids Skau:

- - - Stemningen blandt Fjendens Tropper, især blandt Preusserne, er forknyt, da de baade indsee, man har narret dem, idet de bildte dem ind, at de skulde hjælpe et forkuet og undertrykt Folk, som de nu see er langt lykkeligere, end de nogensinde selv have været, og tillige tror de ligefrem selv at skulle slagtes af de forenede Danske og Svenske, hvilke sidste man troer ere ankommen til Jylland. En Preusser yttrede: vi kunne have ondt nok ved at bjerge os over for de glubende Danske; men naar Svenskerne kommer til, bliver det rent galt. -

Om dette Spørgsmaal skriver Redaktør Fr. Fischer: - Jeg maa ved denne Lejlighed tilføje, at a 1 l e Efterretninger, vi have erholdt - og det er ikke faa, og dertil fra meget forskellige Egne - er overeensstemmende deri, at Preusserne ere meget modfaldne. Officerer og Menige, og især de sidste, yttre deres Forsagthed uden Tilbagehold. De veed, sige de, at de ere komne her ned i Landet for her at lægge deres Been; dragende Nord paa have de paa adskillige Steder sagt et sidste Levvel til deres Værter, da de vidste, at de ikke kom tilbage, - og hyppigt gentager sig den Forsikring, at de ved første alvorlige Modstand vilde strække Gevær - _ _ - Redaktør Fischer 
virkede en Tid, trods sin Invaliditet, som Spejder fra de danske Vagtskibe i Bæltet. ${ }^{40}$ )

Laurids Skau skrev den 17. Maj til Kaptain Læssøe: Inat ere tvende af mine Udsendinge - Bønder fra Slesvig - kommen hertil og meddeler følgende: De vare gaaede fra Hoptrup til Haderslev og Christiansfeld, hvor Hovedkvarteret nu er. Igennem Haderslev var der passeret, efter Indvaanernes Fortælling, ialt 16 Kanoner, som maatte findes Nord paa. Der var kun enkelte regulaire Tropper i Haderslev, men derimod en heel Mængde paa Christiansfeld, efter en Soldats Fortælling omtrent 1600 Mand, af forskjellige Vaabenarter og lutter Preussere. Da det var om Aftenen, de vare der, saa bleve der lagt dem nogle smaa Hindringer i Veien i selve Byen, og da der ingen Danske findes i Christiansfeld, saa foretrak de at tale med Forposterne, som syntes at være overbeviste om, at der skulde staae et Slag ved Kolding - som de udtrykte sig paa Slesv. Holsteens Grændse. (Se foran General Wrangels Plan med Vonsild). En Underofficer yttrede, at det vilde nok blive en haard Tour, thi hans Lieutnant havde sagt, at "die verdamten Schweden« vilde hjælpe Danskerne, og, tilføjede han. "saa blive vi slagtede allesammen, da vi ikke engang kan flygte«, fordi de danske Bønder, som de havde omkring dem, vilde hjælpe til. Paa Spørgsmaalet, hvoraf de vidste dette, svarede Underofficeren, jo, deres lumske og sure Ansigter vidne tilstrækkelig derom, og hver Dag finde vi skjulte Vaaben. - I Bønderbyerne mellem Christiansfeld og Kolding vare Tropper indkvarterede, men de fleste vare, efter Sigende, i og omkring Kolding. Forresten beklagede Preusserne sig over, at de ingen rigtig Natteroe kunde faae, fordi de baade skulde passe paa Bonderne ${ }^{\star}$ ) og tillige være parate til at modtage nogle hurtig

*) Om den Maade hvorpaa Preusserne gik frem paa dette Omraade, vidner følgende om Møller Staal, Taarning Mølle: Som fremtrædende Dansker og Leder af Folkevæbningen i Haderslev Østeramt maatte han selvfølgelig flygte, da Fjenden besatte Landsdelen. Gaarden blev besat af Preusserne, og gentagne Gange foretog disse Husundersøgelser, hvor ikke engang Møblerne blev skaanet, og hver Krog, ogsaa i Møllen, blev gennemsøgt for at finde Papirer, Vaaben 
fremrykende Fjender, da de troede at skulle overrumples af den danske Arméé. - Bonderne eller mine Udsendinge bleve nøie udspurgte om, hvad de havde hørt om den danske Armees Styrke; men derom vare de selvfølgelig uvidende. Den ene af dem var forslagen nok til at sige, at han troede at kunne faae dette at vide af Preusserne, som han meente havde udforsket dette, hvortil svaredes, at man antog omtrent 15,000 Mand i Eet og Alt. - Derpaa afsendte jeg dem straks igen med Ordre til at gaae til Kolding og tale med Kjøbmand Varming og fra ham skaffe skriftlig I'nderretning om, hvormange Tropper der vare, - forudsat at Varming endnu var der. - - - - - Om activ Hjælp fra Rusland her $\mathrm{i}$ Landet, enten tilsøes eller tillands, vidste Preusserne Intet, derimod vidste de godt, at en russisk Armee truede den preussiske Grændse. - De danske Bøncler begyndte at hæve Hovedet, da Rygtet havde sagt dem, at en stor Arme snart vilde komme og jage Tydskerne ud. Enkelte sl. holst. Familier begyndte at tænke paa Flugt, da de frygtede de danske Soldaters Hævn. - - - -

- Dette Brev sluttede Laurids Skau med, at maar der nu kommer andre af mine Udsendinge tilbage - jeg venter To vil jeg sandsynlig komme i Forlegenhed for Penge. Hvis Deres Velbaarenhed vilde have den Godhed at tilstille mig Anviisning paa en Sum, vilde jeg derfor blive Dem særdeles forbunden; thi uden Penge kan man ikke faae Folk ud af Stedet."

Selvfølgelig udførte Laurids Skaus Spejdere ikke Arbejdet gratis. De skulde have til deres eget og Familiens Underhold, de skulde ogsaa have eventuelle Udgifter under Farterne be-

o. l. Seks Skildvagter med skarpladte Geværer stod Dag og Nat posteret rundt i det Indre af Beboelseshuset, og i Begyndelsen blev alle Husets Folk, ogsaa Møllerens Kone og Børn, kald t op tre Gange om Natten for at talles, om ingen skulde vare flygtet fra Møllen. Da man intet fandt, forte Militaret Moller Staals æaldste Søn bort og kastede ham i Fængsel. - Det er forstaaeligt, at der under saadanne Forhold ikke blev Tid til megen Nattesøvn. - Efter Angrebet paa Haderslev 29. Juni maatte Møller Staal igen flygte, efterladende alt sit Gods, en syg Hustru og 12 Born i Fjendens Hander. (J. P. Laurent: Livet i Felten). Under Vaabenstilstanden erklæredes Møller Staal, der ikke kunde komme hjem, uden videre konkurs, og en Nabomgller blev sat til at bestyre hans Ejendom. (J. S. 16) 
talt. Manden, der sejlede dem til Kysten paa Fastlandet og hentede dem igen nogle Dage efter, skulde ogsaa have Betaling, og den kunde endda blive stor, hvis Faren var særlig overhængende. Disse Udgifter kunde Laurids Skau ikke selv bestride, det var heller ikke Meningen, og Krigsministeren havde lovet, at Pengene skulde blive ham anvist igennem Hovedkvarteret eller gennem Stabschefen selv. Laurids Skau kunde altsaa med Føje bede om Penge.

Den 19. Maj gav Krigsministeren Overkommandoen Paalæg om at søge tilvejebragt et godt Efterretningsvæsen, hvortil der føjedes det praktiske Raad, at man ikke skulde spare paa Pengene dertil. ${ }^{41}$ )

Samme Dag afsendte Kaptajn Læssøe følgende til Laurids Skau: Jeg takker Dem meget for de meddelte Oplysninger, som jeg haaber, De vedbliver at forøge. En Anvisning paa $200 \mathrm{Rbd}$. følger vedlagt, hvorfor jeg udbeder mig tilsendt en Tilstaaelse lydende paa mit Navn. ${ }^{42}$ )

Den 25. Maj sender Kaptajn Læssøe $100 \mathrm{Rbd}$. og ønsker: at De fortsætter med saa megen Kraft som muligt. ${ }^{43}$ )

Efter det foregaaende vil Læsenen sikkert have antaget, at et vist Samarbejde bestod mellem Efterretningsvasenet og Besætningen paa Vagtskibene i Bæltet og tillige mellem disse og Befolkningen paa Kysten, og det var ogsaa Tilfældet. Ofte sejlede Beboerne paa Kysten (jvf. Red. Fischer) ved Nattetid selv ud til Skibene - skønt det var forbudt under Trusel om streng Straf at sejle om Natten - og afgav Beretning, som derefter gik videre. Skulde ncgen af Laurids Skaus Spejdere i Land paa Kysten, og der var Vanskeligheder, sejlede de ud til Vagtskibene og opholdt sig der om Bord, til det belejlige Tidspunkt for Landsættelsen kom. Mandskabet roede da somme Tider for dem og hjalp dem i Land, ligesom Spejderne tyede om Bord i Vagtskibet, inden de paabegyndte Sejladsen til Assens. Fra saadanne Ture haves følgende Beretning. Fortælleren hørte 
til det Rantzauske Frikorps, der omkring 15. Maj overtog Kystvagten fra Aarøsund til Aabenraa: $:^{44}$ )

Kort efter, at Korpset havde overtaget Kystvagten, opdagede et Medlem, "der kendte baade Egnen og Sproget", at Marinesoldaterne fra Vagtskibene stod $i$ stadig Forbindelse med dansksindede inde paa Kysten og landede snart her, snart der paa nærmere betegnede Steder. Friskaremændene vidste altsaa omtrent, paa hvilket Sted de skulde rette deres Opmærksomhed.

En Nat omkring Kl. 12 bemærkede Vagten Lys ikke langt ude paa Bæltet, kort efter hørtes Aaretag. Hurtig blev Vagtmandskabet samlet. Fra dets Skjul saa de et Baadsmandskab lande og blive modtaget af en Fisker, der førte dem ind i Skoven.

For at blive styrket efter de udstaaede Strabadser blev Sømændene af Fiskeren ført til et Hus, hvor de gik ind. De maa have fult sig sikre og satte end ikke Vagtposter ud. Friskaremændene kunde derfor uden Vanskelighed trænge helt hen til Huset og omringe det.

I Stuen gjorde Sømændene sig det behageligt. Deres Vaaben havde de stillet fra sig ved V'æggen og sad nu og hyggede sig ved en Tevandspunch, "Danskernes Yndlingsdrik«.

Da det andet Glas var drukket, og Snakken rigtig kommen i Gang, gav Føreren Tegn, og ind stormede Friskaremændene og spærrede Vejen til Vaabnene. Marinerne sprang op; men paa Modværge var det ikke til at tænke, dertil var Overmagten for stor. Et Par sogte at undslippe ad en Bagdør, men blev grebet af en Vagt, der stod uden for Døren.

Fangerne blev for Natten indespærret $i$ et Skovfogedhus $i$ Nærheden. Næste Morgen blev de transporteret til Haderslev, derfra til Rendsborg.

Senere samme Nat blev der sat Spejdere i Land længere Nord paa ad Aarøsund til. Der gik det bedre. Marinesoldaterne kom i Haandgemæng med de to fjendtlige Vagtposter. De 
blev begge saaret, den ene lykkedes det at undslippe, den anden blev slæbt ud paa Vagtskibet.

- Det var ventelig, at ikke alle Forbindelser, der blev stiftet inde paa Kysten, var gode. Om en saadan fortalte Skræder Jens Mogensen, Aarø, mig.")

I 1848 boede Lorens Caspersen - for Nemheds Skyld kaldet Casper - i Aarosund. Han havde en lille Jagt, som han sejlede med i de nærmeste Farvande.

Casper vilde gerne tjene Penge, men Fragtsejladsen gav for lidt. Han tyede da til andre Kilder, som kunde give ham det eftertragtede Mammon, en af disse var Smugling.

Saa kom Krigen, Landsdelen blev besat af Fjenden. Engang imellem kom tyske Patrouiller til Færgestedet, men drog som Fegel hurtigt bort igen.

*) Man plejer at sige, at munitlige Overleveringer kan man ikke stole paa, de forandres fra slaget til Slagt.

Naar jeg nu to Gange tillader mig at bruge mundtlige Kilder og lader en Mand paa 85 Aar fortalle mig Historier, som han i sin Barndom har hort af sin Fadter, der igen oplevede dem sorn ung. saa skylder jeg tt fremfore, hvad der taler for, at ovennævnte ikke gælder den Mand, der her er Tale om, saa Laseren kan modtage hans Fortælling godt.

Som Ireng har han siddet og lyttet. Det var i de Dage og i et Hjern, hvor man fik Historien ind med Modermælken, den blev nynnet over de smat i Vuggen, Fader fortalte den til Sxn, maaske var det Beristefarler, der gjorde det, og denne igen videre. - Og hvad han horte, hed sig fast, og det blev sicldende, lige til de mindste Detailler.

Det var Hjemstavnshistorie, de gamle fortalte, - let var det eneste, de havile Brug for -. om hvad deres Forfadre havde gjort og sagt, hvordan de havile baaret sig ad med dette eller hint. - Og han har forstanet at bevare, hvad de gamle fortalte, men ikke alene det, han har ogsaa forstat at vurdere det og drage sine Slutninger der ud fra, saa Historien for ham blev noget mere end blot og bar $\mathrm{Hi}$ storie, den blev et Stykke Kulturhistorie og Etik - en Lære paa godt og ondt.

Som faa ejer han den Evne at kunne leve sig ind i Historien, saa den er blevet en Del af ham selv. Og han fortæeller den igen paa en Maade saa levende, at man uvilkaarlig betages, ikke mindst af den Fortællekunst, han lægger for Dagen. Tonefaldet, Mimikken, alt er saa pragtfuldt naturligt, en Skuespiller vardig, saa man rives med og føres ind $i$ den Verden af Hjemstavnshistorie, hvor Jens Mogensen selv saa gerne dvæler.

Hvad han fortalte mig om Friskarerne i Aarosund, var i fuldstændig Overensstemmelse med de skriftlige Kilder. Den Mand, der nu skal fortælles om, har Jens Mogensen selv kendt. 
Chefen om Bord paa Vagtskibet vilde gerne vide Besked om Fjenden og kom engang imellem i Land, men vilde selvfølgelig nødig i Selskab med Fjenden - og kom i Forbindelse med Casper.

Her var Penge at tjene, og saa var Casper Manden, der kunde hjælpe. Han skaffede Oplysninger, og for at vejlede Vagtskibets Chef med Hensyn til, hvornaar denne kunde komme i Land, aftalte de, at var der fjendtlige Patruiller i Nærheden, skulde Casper hange et hvidt Lagen ud paa en Tjørnehæk, der gik langs Huset. Casper boede ved Stranden lidt Nord for Færgestedet.

Men Fjenden vilde selvsagt ogsaa gerne vide Besked - og kom ogsaa i Forbindelse med Casper, hvis Kærlighed til Pengepungen trods alt var større end Kærligheden til Fædrelandet.

En Tid gik. Men saa fattede Fjenden Mistanke om, at det med Casper ikke var, som det skulde være, dog uden at kunne bevise noget; men Casper fandt det raadeligst, forhadt som han desuden var blevet af Befolkningen, at fortrække til Halk og boede hos en Bekendt der.

Danskerne havde imidlertid ogsaa fattet Mistanke til Casper og vilde gerne have Fingre i ham. Men hvordan skulde det lade sig gøre?

Paa Aarø boede en Mand ved Navn Grønberg. Han havde $i$ sin ,Ungdom ligget ved Dragonerne i Aarhus og var en god dansk Mand. Han tilbød at skaffe Casper til Veje.

Planen blev lagt. Vagtskibet skulde lagge en bemandet Chalup i Aarø Vig, selv skulde det gaa om paa den anden Side af Øen, saa alt aandede Fred og ingen Fare, Grønberg skulde saa ro over og se at faa Casper med tilbage. Naar man i Chaluppen saa Baaden saa langt ude $i$ Sundet, at den ikke kunde naa at komme tilbage, skulde den komme frem og tage Casper.

Grønberg drog af Sted. Han roede sin Baad op til Bankel Sø, gemte den der og gik op til Halk. Her traf han Casper. Over for Casper klagede Grønberg sin Nød. Han skulde 
hjem til Aarø, men ingen i Aarøsund turde sætte ham over for Tyskerne - om han, Casper, ikke vilde gøre diet, han havde jo en Jolle ved Halk Strand, han skulde faa en Specie for det.

Caspers Kærlighed til denne Verdens Goder fornægtede sig heller ikke denue Gang. Specien var for ham som Flæsket i Fælden for Musen. Vel var han bange for Danskerne, men hvis han nu satte Gronberg i Land ved "Bakklau«, Sydspidsen af Aarø, mon det saa ikke gik?

Efter nogen Tids Spekuleren slog Casper til. Vagtskibet var jo ogsaa borte!

De sejlede ud, og - da de kom i Narheden af Aarø, kom Chaluppen, roet af fire Par stærke Arme.

No æ a færre! raabte Casper og strakte begge Arme i Vejret, men roede saa alligevel til af alle Kræfter, naaede Land og skjulte sig i Kornet.

Men der var intet at gore. Officeren i Baaden sammenkaldte Øens Befolkning, besatte med dem Strandkanten og begyndte en Eftersøgning.

En af Aarøboerne, Jep Kræersen, gik Vagt langs Strandkanten ved Bakklau. Paa dette Sted var der en Mrengde Rævegrave. Som Jep gaar langs Strandkanten, ser han rent tilfældigt hen paa en Rævegrav i Skrænten - og ser Caspers Hoved i Aabningen.

Ja, Casper, a vill nok go aa laed, som a itt haar sitt dæi men de' nøt'er dæe itt nowe. Hiele Aarø a besat, aa di vill lied ætter dæj, til di finder dæj, sagde Jep, som alligevel, da han saa Casper i hans dybe Fornedrelse, ynkedes over ham.

Ja, a ka li saa godt gi mæ øwer - a æ saa forhadt baade a Tyskere og Danskere, sagde Casper og krob frem fja sit skjul. De fulgtes ad hen til Officeren, og Casper kom til Assens, hvor han sad fangslet, til Krigen var forbi.

Skønt Flertallet af Aarøboerne var gode Danske, var den Maade, Casper var blevet fanget paa, dem dog alligevel imod, og de forfulgte paa forskellig Maade Grønberg, saa han maatte ty til Chefen paa Vagtskibet. Han sammenkaldte Befolkningen 
paa Øen i Iver Hansens Gaard og holdt her en Tale til dem. Saa blev der Ro.

For dog - ogsaa i Tilfælde af Tilbagetog - at faa Erstatning for den Skade, den danske Blokade paaførte tysk Handel, - paalagde General Wrangel den jydske Befolkning en Brandskat paa 2 Millioner Specier, 8 Millioner Kroner, at betale inden 28. $\mathrm{Maj}^{45}{ }^{45}$

Han forudsaa, at der kunde opstaa visse Vanskeligheder ved Inddrivelsen af Beløbet og fornyede derfor sit Krav om en Forstærkning paa 10000 Mand. *)

Generalen fik dog hverken Forstærkning eller Penge.

Befolkningen nægtede at betale, og den 23. Maj modtog Generalen fra den preussiske Regering Ordre, dat. 22 . Maj, til at forlade Nørrejylland og betale tilbage, hvad der muligvis var betalt af Brandskatten.

I Berlin havde man faaet nok nu. Den preussiske Krigsminister havde paa Kongens V'egne anmodet General W'rangel om at tilbagekalde Ordren om Brandskatten og ophøre med Fjendtlighederne, da det ganske vilde ødelægge Diplomatiets Bestræbelser, men Wrangel sagde Nej.

Dog blev der altsaa nu sagt Stop. Forbundsstaterne vilde ikke afgive flere Tropper. I Berlin ulmede det endnu efter Martsrevolutionen, og man behøvede Soldater. Trykket paa den danske Regering ansaa man for for svagt. Fra Als truede Danskerne i Flanken. Alt i alt var Besættelsen upopulær i Berlin.

General Wrangel blev vred, da han modtog Ordren til Tilhagetog. Tror de Herrer i Berlin, jeg er forrykt. Jeg bliver staaende, til jeg faar Skatten, udbrød han. Senere kom han dog til

*) Brandskatten og den haurde Behandling, Befolkningen i Vejle Amt $\mathrm{i}$ det hele taget var ude for, fremkaldte megen Deltagelse hos den øvrige danske Befolkning, der rettede haarle Bebrejdelser mod Regeringen. Kongen udsendte sin Proklamation: Trofaste Jyder (Orla Lehmanns efterl. Skr. II 301). Grundtvig digtede den smukke Sang: Fædreneland ved den bølgende Strand. (Trykt i Ugebl. Danskeren for 24. Maj 1848), og Hærledelsen lagde Planer om en Landgang paa Jyllands Kyst. 
Besindelse og gav Befaling til Opbrud med de Ord: Vi drager bort som Narre. ${ }^{46}$ )

Om Laurids Skaus Virksomhed i denne sidste Periode medtages de tre følgende Breve:

Velbaarne Herr Capt. v. Læssøe!

I dette Øieblik, Aften Kl. 9, kom en af mine Folk, som idag med stor Møie har listet sig ud af Haderslev; han maatte give en Fisker 20 rd. for at sætte ham over til Brandsøe, hvorfra han nu kom med en Skipper. Han meddeler følgende:

Den provisoriske Regjering har forbudt alle Rekrutter at indfinde sig $\mathrm{i}$ dansk Tjeneste og befalet dem at være parate paa nærmere Ordre fra Rendsborg. Paa Grund heraf har mange af det unge Mandskab besluttet at stjæle sig herover ved given Lejlighed. Tvende ere allerede ankommen. - Haderslev har nu faaet stærkere Besætning; omtrent 800 Mand Infanteri af lüneborgske Tropper og nogle hannoveranske Dragoner, der gjøre dem kjendelige ved raae Opførsel. I Christiansfeld er Hovedkvarteret; men sardeles mange Tropper findes ikke før i Nærheden af Kolding. En Mængde Friskarefolk er reiste til Rendsborg; men nogle Hundrede ere endnu tilbage, som gjør Strandvagterne; især have de besat Ørbyhage i Vonsbæk Sogn stærkt, hvilket er slemt, fordi vi der havde et godt Landingssted for vore Afsendinge. - Ved Aarøesund har vore Søkrigene truffet godt igaar med deres Kugler; thi alle Haderslevske Læger bleve i største Zil hentede. Det er lutter Friskarefolk, som der ligge. $--\ldots-\ldots$

Assens, 23. Mai Aften Kl. 91/2.

Arbødigst

Velbaarne

1848.

Laurids Skau.

Herr Captain v. Læessøe!

Inat er der atter kommen een af mine Udsendinge, som meddeler, at baade preussiske Soldater og Friskarefolk anslaaer deres hele Styrke til 24000 Mand, de Frivillige samt de sl. holst. Tropper iberegnet, og at de ikke kunne vente flere Tropper, 
med mindre de frie Stæder Hamborg, Lybek og Bremen skulde blive istand til at udruste Besten af deres Contingent. Dertil er imidlertid efter Breve fra Agent Bruuns Søn i Hamborg ikke Skin af Sandsynlighed. - Forleden Dag kjørte en Mængde Krudtvogne igjennem Haderslev til Apenrade; Artilleristerne var dansktalende Folk, og naar man spurgte dem paa Tydsk, svarede de paa Dansk, og kaldte sig gode Danske. - - - Saavidt der kan skjønnes, lader Fjenden en Mængde Transportvogne, Krudtvogne o. s. v. gaae sydpaa. - Der holdes overordentlig streng Strandvagt af smaae Friskareafdelinger, og paa de vigtigere Punkter komme af og til Dragonpatruiller, f. Eks. til Aarøsund, hvorhen man iforgaars havde transporteret en Mængde Baade fra Haderslev, paa hvilke de vilde seile ud og entre Kutteren Neptunus. - - -

I Løverdags var jeg selv iland i Vilstrup Sogn og talte med enkelte Mænd, med min Kone og min Avlskarl, som bragte mig noget Linned o. s. v. - Neppe to Timer efter, at jeg var seilet bort, var min Gaard omringet af Friskarefolk, som toge min Avlskarl og en anden Mand, der havde talt med mig, til Fange og førte dem lige til Rendsborg. Det bliver mere og mere vanskeligt at vedligeholde Forbindelsen med Kystbeboerne og vil tilsidst blive umuligt, hvis der ikke engang imellem gjøres Landgang af nogle Soldater, som kunne snappe nogen af disse Friskarefolk op. Det vilde ikke være synderlig vanskeligt. Petersen fra Heils paastaar, at han med 300 Jægere tor paatage sig at rense hele Kysten. *) - Jeg er meget urolig for tvende af

*) Laurids Skau har tidligere omtalt denne Petersen fra Heils. I et Brev skriver han, at: den bekjendte Hr. Petersen fra Heils har været iland Natten over i Heils Ladeplads og fortæller, at der i Bjært Sogn ligger 60 Friskaremænd, som Præsten har rekvireret, da han frygtede, og det med Rette for, at Bønderne vilde slaa ham ihjel, formedelst hans tydske Sympatier.

Andetsteds bliver han kaldt: de Danskes Vejviser ved Flensborg - og det antydes, at han hjalp til med at faa Slesvigerne til at gaa i dansk Tjeneste. -

Hegermann-Lindencrone omtaler ham i sine Rapporter som Candidat Petersen fra Heils.

Formodentlig er han ogsaa en af Flors Studenter. Om Efteraaret nævnes han i "Dannevirke« som Oberst Hansens Adjudant og var 
af mine Folk, som allerede skulle være kommen. Baadene, som jeg har sendt over for at hente dem, komme tomme tilbage. Jeg har i Dag atter afsendt to bemandede Baade, og da det ikke er uden Fare at berøre Kysten, saa maae jeg betale meget stærkt, hvilket forskrækker mig, eftersom mine Penge snart kan slippe op. Jeg maa derfor udbede mig Deres Velbaarenheds nærmere Bestemmelse, om jeg desuagtet skal endnu vedblive nogle Dage, da jeg i saa Tilfælde idetmindste vil behøve $100 \mathrm{rd}$. Jeg har idag sendt desuden en Baad ud til Kutteren, da det hedder, at Krüger fra Beftoft og Petersen fra Heils skulle være der; i modsat Fald ere de opsnappede. - Næste Nat vil jeg sely seile over til Kysten for at recognoscere og om muligt frelse mine Afsendinge.

Assens, den 24. Maj 1848, Form. Kl. 10.

Erbødigst

La urids Sk a u.

Velbaarne

Herr Capt. v. Læssøe!

Kjøbmand Frederiksen fra Kolding, med hvem jeg hemmelig har staaet i Forbindelse, er i dette Øieblik ankommen hertil og meddeler, at i dette Øieblik ere alle Fjender ude af Jylland samt altsaa ogsaa af Kolding. - Formodentlig ved De allerede dette, men da Kjøbmanden har haft Generalkommandoen i sit Huus, og af Stabsofficererne har hørt, at alle dem, der var i Kolding, skulle lige til Flen s b or g, hvor Marchen f o reløbig ville gjøre Holdt, samt at dette tilsyneladende er en Frugt af et Krigsraad, der holdtes i Kolding, hvori Beseler og Tiedemann have taget Deel, - saa har jeg dog troet at bur-

fra Omegnen af Haderslev. I en militær Mandskabsliste omtales en Jens A. Petersen, f. 20. 4. 1824 i Heinesminde (Heilsminde)?

Karak. Leutnant af Krigsreserven 10. 9. 48.

Karak. Kaptain af Krigsreserven 1864.

Adjudant ved 9. Brigade 1864 .

Afskediget i Naade som Kaptain 30.12. 64 .

Han var som faa bexret med Slesvigholstenernes særlige Had, hvad en Korrespondance i "Neue freie Presse" fra Haderslev 2. Septbr. 1849 viser tilstrækkeligt. 
de underrette Dem om dette pr. Estafette, især da det synes sandsynligt, at Fjenden kunde sætte sig fast - om ikke før saa i Egnen ved Bau, hvor Terrainet egner sig til Slag.

Assens, d. 26de Mai 1848, Middag Kl. 12.

AErbødigst

La urids Skau.

I Henhold til Befalingen dirigerede General Wrangel Tropperne tilbage til Egnen mellem Flensborg og Tonder. Efter dem fulgte de danske Spejdere. Allerede den 26. var nogle af dem i Kolding, hvor man netop gjorde op med forskellige, som under Fjendens Herredømme knap havde været saa fædrelandske, som man kunde ønske. Blandt de stærkt mistænkte var Stænderdep. A. Petersen, Dalbygaard.

Fra Laurids Skau har vi følgende:

Velbaarne

Herr Captain v. Læssøe!

Den Sømand, som jeg sidste Søndag havde med mig til Odense, og som De der talte med, er idag kommen tilbage efter at have gennemstreifet Sundeved og gjennemgaaet de vanskeligste og besværligste Forhold. Han kom derfra over til Als og har givet Høistkommanderende sammesteds udførligt Referat, men da hans Beretning nu er 3 Dage gammel, saa vil det være lidet fyldestgørende her at gjentage den. Kun saameget skal jeg dog anføre, at Besætningen i Sundeved var midt i Ugen 3600 Miand, med 2 Kanoner i Dybbøl og 2 i Nybbel; men flere havde været der, som nu vare førte til Krusau, hvor de skulde bruges til at skyde med paa Hekla, Steen Bille, naar han atter kom der. Paa Gravensten stod 10 Kanoner, og Hertugen af Aug. spadserede i Haven. Et Rygte i Sundeved fortalte, at Prindsen af Aug. var dødeligt saaret. En hannoveransk General er skudt og begravet i Barsboll i Sundeved. - Et Kavalleri Regimente er gaaet til Flensborg kommende nordfra midt i sidste Uge. 
Jeg har idag været omkring paa Kysten for atter at landsætte et Par af mine Folk; men ikke et eneste Sted er dette muligt, da man passer paa, som om man vilde fange Fugle. Varnitshoved og den nærmeste Omegn er besat med Friskarefolk, rigelig 300 Mand, under Kammerjunker Krogh. Lige fra Halkhoved til Sønderborgfjord er det forresten ganske tæet besat med Dragoner, mest eller maaske alle Hannoveranere, og det i Bøsseskudsdistance fra hinanden. Min Karl, Sømanden, har forresten reist i Sundeved som Kornpranger fra Flensborg med Kornvægt i Lommen og har købt omtr. 200 Tdr. Havre. Da han seilede fra Land i en Fiskerbaad, som han maatte kjøbe, da han mærkede, han blev mistænkt, peb Kuglerne fra Dragonerne om Ørene paa ham.

Assens, d. 28. Mai 1848.

Erbødigst

Laurids Skau.

- Den 25. Maj om Aftenen kom der Bud til General Schleppegrell, at Fjenden trak sig tilbage. Meldingen lod han gaa videre, og en Styrke blev samlet ved Middelfart under Oberst Juel. Denne Styrke, Højre Flankekorps, rykkede langsomt efter Fjenden og besatte Haderslev med Avantgarden skudt frem til Hoptrup.

Efterretningsvasnet antog nu et større Omfang, og der blev herefter ført Tilsyn med alle rejsende. Laurids Skau fortsatte foreløbig sin Virksomhed fra Haderslev og havde mange Mand til at hjælpe sig. I et Brev til Kaptain Læssøe nævner han engang, at han har syv Mand ude. Endvidere ser det ud til, at det er ham, der har haft Opsynet med de rejsende og politisk mistænkte.

- At Fjenden har regnet med disse Mand og respekteret dem, derom vidner en Udtalelse af General Wrangels Søn, der var Officer under sin Fader. En Dag kom han til den danske Forpostlinie og skulde vente nogen Tid. Under Samtale med Forpostkommandoren udtalte han:

Vi er med Hensyn til Efterretninger meget slet stillede i Forhold til Dem, til Deres Disposition staae brave Mænd, de 
bedste Patrioter, der vove Livet for deres Fædreland, til vor kun Udskuddet, som lader sig købe til at forraade deres Fædreland; der er kun faa saadanne at faa fat $\mathbf{i}$, og de er naturligvis ikke til at stole paa. ${ }^{47}$ )

Det er Fjendens Honnør til de gode danske Mænd, der kæmpede paa denne Valplads.

Frovin Jørgensen.

\section{Kilder:}

1) Sdj. Aarb. II 1937, Side 228 ff.

$\left.{ }^{2}\right)$ Wilhelm Hamm: Freischaaren-Novellen.

3) Se Generalstabens Værk: Den dansk-tyske Krig 1848-50, Side 498 ff, nævnes senere G. V.

4) Ludvig Hertel: H. W. Hertel.

5) Krigsmin. Ark. Feltarkiv 1848-50, Nørrej. Armek. 1 a1. I. S. 15.

6) Vejle Amts Arkiv: Indk. Breve, Lægdsvæsen og Militærsager 1848. I. $65 \mathrm{~d}$ (Viborg).

7) G. V., Side 183.

8) Krigsm. Ark.: Feltark. 1848-50, Nørrej. Armek. 1 c 2. I. S. og U. S.

9) Krigsm. Ark.: Feltark. 1848-50, Nørrej. Armek. 1 a1. I. S. 17, nævnes senere: I. S. 17.

10) G. V. Side 183.

11) I. S. 17.

12) Kgl. Bibl. (Ny kgl. Saml. 1727 Fol.)

13) I. S. 17.

14) I. S. 17 .

15) Side 634.

16) I. S. 17.

17) N. Neergaard: Under Junigrundloven, Side 251.

18) Se ang. Stillingen i Preussen: samme, Side $83 \mathrm{ff}$.

18) Se Kildeangivelserne til "Aarøsund i 1848«, Sdj. Aarb. II 1937.

20) Orla Lehmanns efterl. Skr. II Side $303 \mathrm{ff}$.

21) Leutnant Melstedts Deltagen i Krigen 1848.

${ }^{22}$ ) Kapt. J. F. Linau: Meine Erlebnisse in der Schl. Holst. Armé.

23) Aarh. Stiftst. 30. Maj 1848.

24) Kolding Avis 15. April 1913.

$\left.{ }^{25}\right)$ Moltkes militæriske Værker: Krieg gegen Dänemark 1848-49.

26) G. V. Side $688 \mathrm{f}$.

27) Vejle Amts Arkiv. (Viborg).

$\left.{ }^{28}\right)$ G. V. Side 689 siger 5 Broer.

$\left.{ }^{29}\right)$ I. S. 17 - efterf. Breve eller Brudst. af Breve, hvor ingen Kilde er nævnt, er fra I. S. 17.

30) G. V. Side 690

31) Om Planer i saa Henseende se G. V. Side 712 ff.

32) G. V. Side 690 f.

33) Se Sdj. Aarb. II 1937. 
34) G. V. Side 701.

35) G. V. Side 634.

$\left.{ }^{36}\right)$ A. D. Cohen: Krigen 1848 og de faldnes Minde.

Se iøvrigt foran om Itzehoer-Dragonerne.

37) Fr. Printzhausen: Der Schein-Krieg mit Dänemark im Jahre 1848.

3s) J. Lorch: Skumlerier og Begivenheder fra Krigens Tid.

$\left.{ }^{39}\right)$ H. A. Malling: Efterladte Erindringer. Se nærmere ang. Preussens Forhold i N. Neergaard: Under Junigrundloven, Side $212 \mathrm{ff}$.

40) P. Lauridsen: Da Sønderjylland vaagnede II Side $265 \mathrm{f}$.

1) G. V. Side 634 .

42) Kgl. Bibl. (Ny kgl. Saml. 1727 Fol.)

43) Samme.

14) Brodersen - Pinneberg: Auf der cimbrischen Halbinsel.

45) G. V. Side 702 f.

46) Baudissin: Geschichte des Schl. Holst. Kriegs.

47) Cai Hegermann-Lindencrone: Mine Erindringer fra Armeen (utrykt).

Af Kilder er benyttet foruden de nævnte:

The o d or Lüders: Denkwürdigkeiten zur neuesten SchleswigHolsteinischen Geschichte.

Prinsen af Nør: Optegnelser.

Danmarks Riges Historie. 